\title{
Long-Term Stability of a Circular Roadway Subjected to Inner Pressure
}

by Seisuke OKUBO ${ }^{1}$ and Katsunori FUKUI ${ }^{1}$

1. Geosystem Engineering, The University of Tokyo, Bunkyo-ku, Tokyo 113-8656

It is the purpose of this study to clarify long-term stability of a circular roadway subjected to inner pressure $\sigma_{r}\left(r_{i}\right)$ together with rock pressure $\sigma_{r}\left(r_{0}\right)$. Circumferential stress at the wall $\sigma_{\theta}\left(r_{i}\right)$ obtained by the elastic analysis is equal to $\left\{2 \sigma_{r}\left(r_{0}\right)-\sigma_{r}\left(r_{i}\right)\right\}$. Therefore, it is natural to consider that tensile failure possibly develops into the surrounding rock starting at the wall if $\sigma_{r}\left(r_{i}\right)$ is larger than $2 \sigma_{r}\left(r_{0}\right)$. A question arises whether it can be properly applied to a circular roadway where large visco-elastic deformation is expected.

A non-linear rheological model proposed by this authors was used to simulate time-dependent behaviour of rock around a circular roadway. It was assumed that inner pressure gradually increases. Results of computer simulation indicate that, at first, the failed region develops and the roadway converges. As time goes by, inner pressure gradually increases, then convergence ceases and finally the roadway diameter starts to increase. We obtained interesting results as follows;

1. Even if $\sigma_{r}\left(r_{i}\right)$ is larger than $2 \sigma_{r}\left(r_{0}\right), \sigma_{\theta}\left(r_{i}\right)$ is still remained in compression provided that Poisson's ratio increases with failure of rock.

2. Post-failure characteristics of rock, that is, slope of descending portion of stress-strain curve in the post-failure region is not so important.

3. Time-dependency of rock is very important, and affects long-term stability of a circular roadway.

Right now, we have only limited information concerning time-dependent behaviour of rock. It is especially important to obtain accurate knowledge concerning Poisson's ratio and behaviour of rock in tension.

KEY WORD : Rock, Simulation, Viscoelastic, Constitutive Equation, Inner Pressure, Roadway

\section{1.はじめに}

著者らは, 以前, 非線型粘弾性論に基ついて開発したコンプラ イアンス可変型構成方程式を用いて, 円形坑道の長期安定性につ いて調べた（大久保・金，1993）。その計算機シミュレーション 結果に上れば，時間の経過に伴って緩み領域が次第に坑壁より奥 へと桩大していく様子を再現できた。また，岩盤の時間依存性の 大きさや, 強度破壊点以降の応力一歪曲線の傾きが, 計算結果に 及ぼす影響についても検討しだ。

さて岩盤内に設けた坑道中に，さまざまなものが眝蔵・保管さ れることが多くなりつつある(例えば稲田，1997）。その際，内 側より圧乡が加わ場合がある。この種の坑道の短期的な安定性 については，弾性論や塑性論で議論できるかもしれないが，場合 によっては数干年一数厅年の挙動をある程度把握しておく必要が ある。そこで本報告では, 内圧を受ける坑道の長期安定性につい て，既報（大久保・金，1993）で用いた構成方程式を採用し，計 算機シミュレーションによって調べてみることにする。

既報では坑道の半径などについて其体的な数值を与えず, 計算

*1998年7月 10 日愛付 10 月 27 日受理

1. 正会員 東京大学教授 二学柔研究科地球システム工学専功

2. 正会員 束京人学助教授 上学柔研究科地球システム工学尃攻

[著者連絡先] FAX 03-3818-7492（東大・地球システム） E-mail : ttokubo@geosys. t. u-tokyo. ac. jp キーワード: 岩盤, シミュレーション, 粘弾性, 满成方程式, 内压, 坑道
結果についても無次元化した值のみ示したが, 今回は問題を分か りやすくするため，廃棄物の地層処分場（PNC，1996；PNC， 1997）を例にとってやや具体的に議論を僬めることにする。たた し, 本研究の目的は, 計算機シミュレーションを通じて, 内压を 受ける坑道の長期安定性の評俩をするにはどのような基礎的検討 が必要が、どのようなデー夕を収集する必要があるかを明暸にす ることであり，坑道内に置加れる充填材や廃裹物の特性・挙動の 詳細は取り报わない。

\section{2. 計算モデル}

\section{$2 \cdot 1$ モデル化}

図 1 に示すように, 半径 $r_{i}$ の円形坑道内にオーバパックに包 まれた廃妄物が一定の間隔 $s$ をって横置きに並べられ，そのま わりにベントナイト等の充填材 (緩衝材) が充填される場合を例 にとる(兽田, 1995；PNC，1997）。オーバパッタは長さL，外 径 $d_{0}$, 内径 $d_{i}$ の月筒状で, 徐々にではあるが表面から磨食して いき, 满食した部分の体積は元の体積の数倍になる。充填材は隙 間なく充填されるものとする。岩盤には，既報（大久保・金， 1993）にならって等方的な地压が加わっているものとする。

以上のような状況を図 2 のうににモデル化する。既報と同様に モデルは 2 次元朝対象で, 平面歪と仮定する。モデルの外周 $r=$ $r_{0}$ に，一定忍力 $\sigma_{r}\left(r_{0}\right)$ を加えることにする。なお，簡単のため 物体力は無視する。坑道内部注静水压 $\sigma_{r}\left(r_{i}\right)$ が加わっており， 


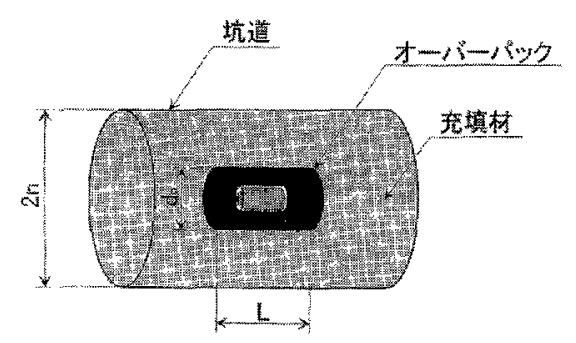

図1 処分場の概念㘣

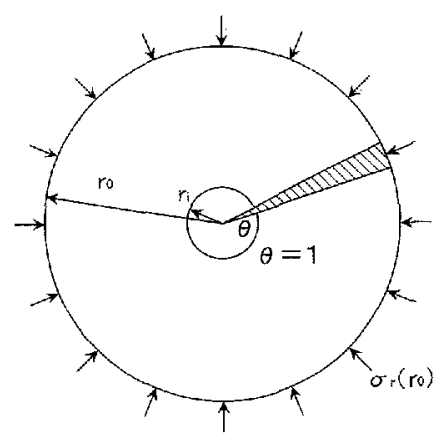

(a)立面図

$\mathrm{\uparrow}$
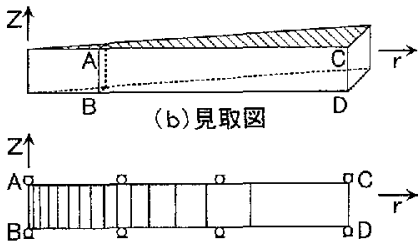

(c) 要素分割

図 2 計算モデルと要素分割。要素分割数は 15 , 外径 $r_{0}=400 \mathrm{~m}$

長さ $s$ 坑道を考えて，その值を次式より計算する。

$\sigma_{r}\left(r_{i}\right)=K\{V(0)-V(t)+\Delta V(t)\}$

$こ こ に, K$ は坑道内部の物質の体積弾性率である。 $V(0)$ は開削 直從の坑道の体積で, 時刻 0 で弾性変形した後の坑道半径を $r_{i}(0)$ として次式となる。

$V(0)=\pi\left\{\left.r_{i}(0)\right|^{2} s\right.$

$V(t)=\pi\left\{\left.r_{i}(t)\right|^{2} s\right.$ は時刻 $t$ における坑道の体積である。 $\Delta V(t)$

は，時刻 $t$ までに腐食によって膨張した体積である。

$\Delta V(t)=C_{v} \pi\left[\left\{d_{0}(0)\right\}^{2}-\left\{\left.d_{0}(t)\right|^{2}\right] L / 4\right.$

腐食によって澎張した体積は，腐食前の体積のC $C_{v}$ 倍になるとし た。 $d_{0}(0)$ は腐食しない前のオーバパックの外径で女る。腐食は 単位時間当たり $C_{r}$ ずつ內部に進行し, 時刻 $t$ では $d_{0}(t)=d_{0}(0)$ $-C_{r} t$ まで進行守る。

\section{$2 \cdot 2$ 検討するパラメータの範囲と構成方程式}

地層処分の具体的な案は決定していないが，仮に表1のような 場合を考えることにする（豊田，1995）。坑道半洤は 0.8〜 1.5 m 程度とみなされるので，1 $\mathrm{m}$ と $1.5 \mathrm{~m}$ の場合を考えることにした。 (1)式からわかる上うに，坑道平径が小さいにど内压の上昇は大 きいが, 経費は安くなるので, 標準条件は $1 \mathrm{~m}$ とした。なお, 表 1 では標準条件を太字で示す。

地表からの深さ忧そらく500～1,000 m と考えられるので, $500 \mathrm{~m}$ と $1,000 \mathrm{~m}$ の場合を検討する。これらの梁度に相当する地 圧はそれぞれ $12.5 \mathrm{MPa}$ と $25 \mathrm{MPa}$ とした。

前述のようにオーバパックは円筒状, 坑道内横置きとし, 坑道 軸方向距離 $s=4 \mathrm{~m}$ ごとに配置されるものとした。この距離は, 周囲の温度があまり上昇しないよう決められるものである。才ー

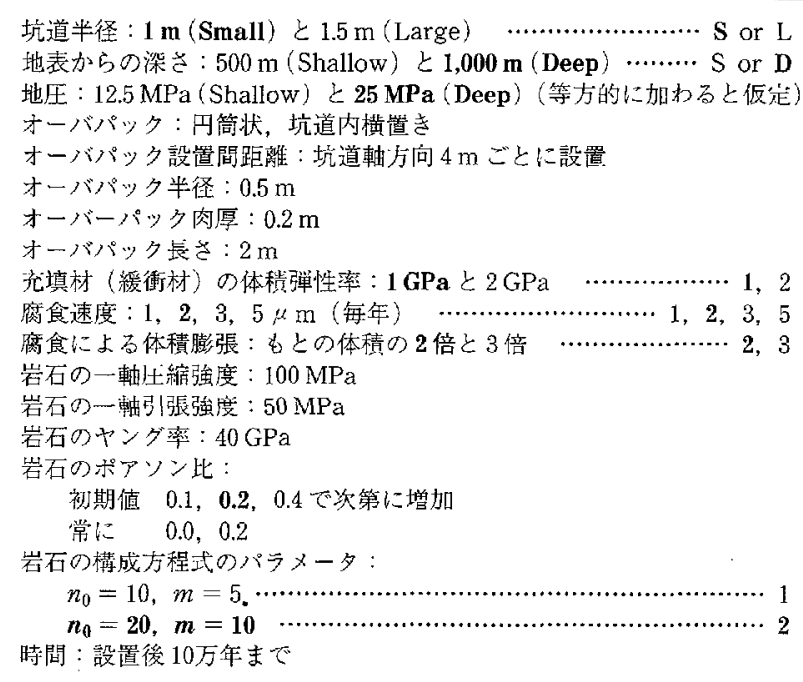

バパック半径は $0.5 \mathrm{~m}$ ，オーバパック厚さ（肉圧）は $0.2 \mathrm{~m}$, オー バパッ夕長さは $2 \mathrm{~m}$ とする。これらの数詣は決定されているも のではなく任意性がある。

坑道内の充填材の体積弾性率については不明な点が多いが, $1 \mathrm{GPa}$ と $2 \mathrm{GPa}$ の場合を検討寸局ことにした。充填材を仮に心 ントナイトとすると, 初期の体積弾性率は $1 \mathrm{GPa}$ よかなり小 さいと予測されるが，次第に压密されて体積弾性率が大きくなっ ていくと推察される。上記の数值はシミュレーション期間にお ける平均値を見積もった結果である。

腐食の進行 (腐食速度) は最初大きい方徐々に小さくなる (PNC，1991)。ここでは簡単のため一定とした。検討した範囲

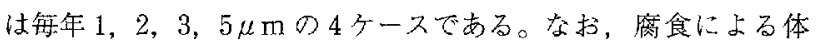
積膨張はもとの体積の 2 㥉と 3 倍を検討することにした。

岩石の構成力程式としてコンプライアンス可変型構成方程式を 採用した（大久保，1992）。

$$
d \lambda^{*} / d t=a\left(\Delta \sigma^{*}\right)^{n}\left(\lambda^{*}\right)^{m}
$$

ここに, $\lambda^{*}$ は初期コンプライアンス $\lambda_{0}$ で嫢格化したコンプライ アンス， $t$ は時間である。 $\Delta \sigma^{*}$ は, 強度 $\Delta \sigma_{0}$ （破壊差応力）で 规格化した差応力である。nは時間依存性を決めるパラメー夕で あり, 一軸㽵縮応力下での值を $n_{0}$, 一軸圧縮強度を $\sigma_{c}$ として次 式より計算する。

$$
n=\left(\Delta \sigma_{0} / \sigma_{c}\right) n_{0}
$$

$m$ は応力一歪曲線の形状を決めるパラメータであり， $m$ が大き いはど強度破墒点以降の応力一歪曲線が急になる。a強度を決 めるパラメータであり，次式で与えられる。

$$
\left.a=\left(1 / t_{0}\right) \mid m /\left(n_{0}+1\right)\right\}^{m /\left(n_{0}-m+1\right)}
$$

$t_{0}$ は強度 $\Delta \sigma_{0}$ を求めるときの試験時間であり，今回は $120 \mathrm{~s}$ と した（大久保・金，1993）。

岩石の構成方程式のパラメー夕 $n_{0}$ と $m$ の)組み合わせは，(20， 10）と（10，5）の場合を主として検討したが，より脆性的な挙 動を示す $(20,20) や(10,10)$ の場合，方るいはより延性的な 举動孝示寸 $(20,1) や(10,0.5)$ の場合も適宜検討する。

岩石は, 一軸圧縮強度 $\sigma_{c}=100 \mathrm{MPa}$ ，一軸引張強度 $\sigma_{t}=5$ $\mathrm{MPa}$ で初期ヤング率 $1 / \lambda_{0}=40 \mathrm{GPa}$ とした。想定したのは花崗

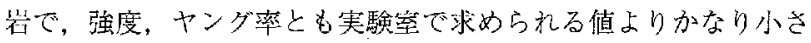
目の值としたが，地表近くの構造物の設計に際して用いられる值 
よりはかなり大きい值である。岩石の破壊基準は， $\sigma_{3}$ を最小主 応力として，次式で与えられるとした（Janach，1977）。

$$
\Delta \sigma_{0}=\sigma_{c}\left(1+\sigma_{3} / \sigma_{t}\right)^{0.5}-\sigma_{3}
$$

ポアソン比レは，コンプライアンスの增大（破壊の進行）に伴っ て堌加するとした。

$$
\nu=0.5-\left(0.5-\nu_{0}\right) / \lambda^{*}
$$

ポアソン比の初期值 $\nu_{0}$ を， $0.0 ， 0.2 ， 0.4$ と変えて検討する。ま た，適宜，ポアンン比を一交 (不変)とした場合も検討する。

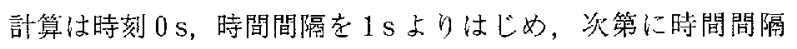
を增大して計算する（大久保・金，1993）。すなわち初期値を，

$$
t_{0}=0, \Delta t_{0}=1
$$

として,

$$
\text { とした。 }
$$$$
t_{i+1}=t_{i}+\Delta t_{i}, \quad \Delta t_{i}=1.1^{i}
$$

\section{3、計 算 結 果}

表 1 に示すように計算条件を設定した。これらの条件の内，ト ンネル半径 $1 \mathrm{~m}$ を標準条件として省略記号 S (Small の略) であ らわす。地表からの深さは，1,000 m を標算条件として省略記号 D (Deepの略) であらわす。さらに, 充填材の体積弾性率, 腐 食の售行，笍食による体積膨張（体積の膨張がもとの体積の何倍 になるか）の標準条件を，それぞれ $1 \mathrm{GPa} ， 2 \mu \mathrm{m}$ (每年)，2偣 とした。また，構成方程式中のパラメー夕 $n_{0}=20, m=10$ を 標染とし，省略記号 2であらわす。標涑条件の場合の省略記号を 順に書くと, SD1222である。

これまでの検討結果によれば， $n_{0}$ が大きいときには時間依存 性が小さく、時問経過に伴う岩籃の変形は小さい。本論文の目的 は，内压を受ける坑道の辰期的な変形と安定性を論じることなの

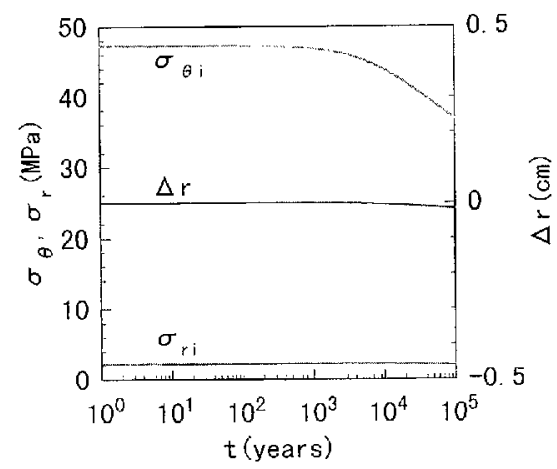

(a) 坑壁にもっとも近い要素の周方向 $の$ 心力 $\sigma_{\theta i}$ ，半径方向の忘力 $\sigma_{r i}$ 执よび坑道半佳の交化 $\Delta r$

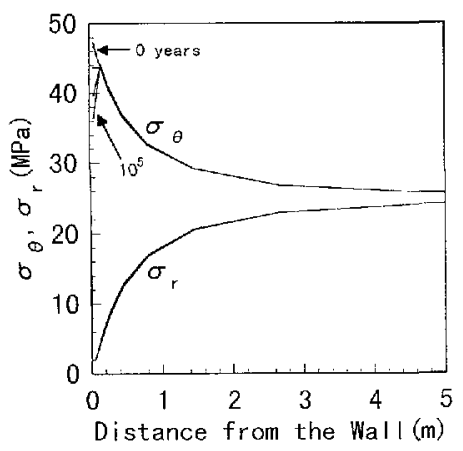

(b) 初期, $10^{3}$ 年後, $10^{4}$ 华後, $4 \times 10^{4}$ 年後, $10^{5}$ 年後の周力向の店力 $\sigma_{\theta}$ と半往方向の応力 $\sigma_{r}$ の半径与向の分布

図 3 充填村はあるが渡食の進行は全くない場合の結果（SD1022）
でまず，このパラメータ $n_{0}$ が比較的大きい場合と小さい場合 にわけて桱討してみる。

$3 \cdot 1$ 時間依存性の小さい岩盤の場合 $\left(n_{0}=20\right)$

内圧の加わらない場合はすでに既竍で報告した。まず，充填材 はあるが腐食の進行は全くない場合の結果を示して扢く（省略記 一号：SD1022）SD1022 は, 坑道直徍 Small, 深さ Deep, 体積弾 性率 $1 \mathrm{GPa}$, 腐食 $0 \mu \mathrm{m}$ （毎年）, 腐食に上り体積 2 倍, 構成方 程式中のパラメータ $\left(n_{0}=20, m=10\right)$ の場合である。図 3(a) に，玾壁にもっとも近い要素の周方向の応力 $\sigma_{\theta i}$, 半径方向の応 力 $\sigma_{r i}$ 掠上び坑道半径の变化 $\Delta r\left(=r_{i}(t)-r_{i}(0)\right)$ を, 1 年後か ら $10^{5}$ 年後まで示した。 1 年後の $\sigma_{\theta i}$ と $\sigma_{r i}$ が坑壁での理論值 (弾性解) と少し違うのは，要素中心の応力を表示しているため と，最初の…年間にわずかではあるが変化したためである。 $\sigma_{\theta}$ は $10^{3}$ 年以降に目立って低下寸るが，叞変化はほとんどない。 坑道の半径はわずかに縮小する。図 $3(\mathrm{~b})$ に, 初期, $10^{3}$ 年徬, $10^{4}$ 年後, $4 \times 10^{4}$ 年後, $10^{5}$ 年後の周方向の灾力 $\sigma_{\theta}$ と半径方向の応 力 $\sigma_{r}$ の分们を示す。坑壁に近い要素の $\sigma_{\theta}$ は時間の経過に伴って 少しずつ低下する。5本の曲楾を描いたが，4本にしか睍えない のは，初期と $10^{3}$ 年後の曲線がほとんど重なるためである。また， 図よりわかるように后の変化はほとんどなく，5本の曲線を重ね て書いているにもかかわらず，1本のやや太目の線にしか見えな い。注目す心゙きは，緩み領域が坑壁近傍にとどまってあまり広が らないことであり，これは充填材の支保効果の他にポアソン比の 仮定にも依存していると思加るるなお。ここでいう緩み領域と は，坑壁より $\sigma_{\theta}$ が最大值をとる位置までを指す。

ポアソン比の影響は，圧肉円筒に関する弾性解（日本機械学会， 1997 ；鵜戸山ら，1968）からも䇥性的には伺えるが，詳しい检討 は考察にゆずるとして，ここではポアソン比の影響が大きいこと を示すた如に，他の条件は図 3 と同じとして，ポアソン此を常に

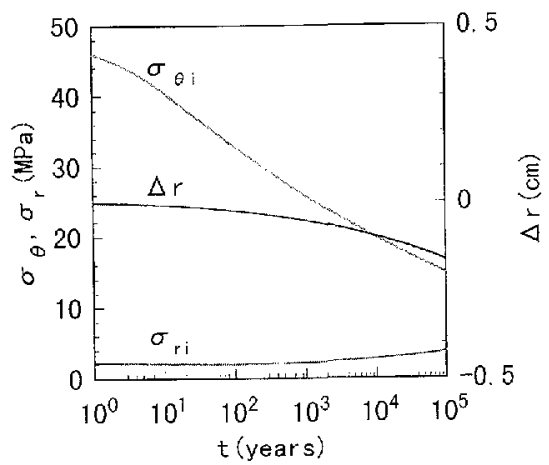

（a） $\sigma_{\theta i}, \sigma_{r i}$ および $\Delta r$ (図 3 と同じ形式)

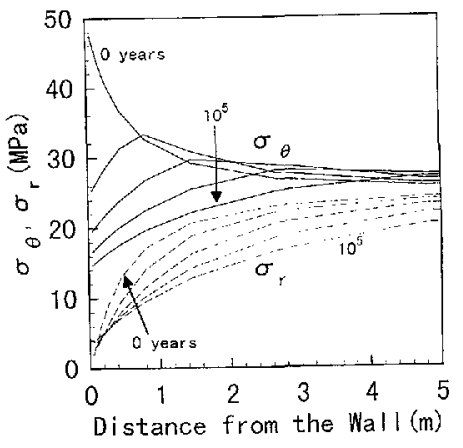

(b) $\sigma_{\theta} と \sigma_{r}$ の半径方向の分布 (図 3 と同じ柇式)

図 4 ポアアソン比常に0とした場合の結果（SD1022） 
0 とした極端な場合を計算してみた。図 3 と同じ形式で，この場 合の計算結果を图 4 に示守。图 $4(\mathrm{a})$ 上り，原低下が激しいこ とが加かる。1 $10^{3}$ 年以降, $\sigma_{r i}$ が少し上昇市るのは，坑道半径が小 さくなって充填枋が圧縮され，その結果，坑道内圧が上昇するた めである。図 4(b)よりわかるように，この場合は，坑壁より $5 \mathrm{~m}$ 以上奥の $\sigma_{\theta}, \sigma_{r}$ まで変化する。

次に，腐食の進行が每年 $1 \mu \mathrm{m}$ と緩やかに腐食が進行する場合 の計算例を図 5 に示す（SD1122）。オーバパックの厚さを $0.2 \mathrm{~m}$ としているので，すべて腐食するのに20万年を要することにな る。計算では，内圧が次第に上昇すると，坑道は広がり， $\sigma_{\theta i}$ か 徐々に低下し， $\sigma_{r i}$ が増加する。あらかじぬ予測できる常識的な 結果といえる。この条件下では，地圧による岩盤の变形は比較的 小さいので弾性計算結果とさして変わらない。腐食の進行を毎年 $2 \mu \mathrm{m}$ とした場合も計算してみた（SD1222）。全般的な傾向は， 図 5 のSD1122 と変わらないので図を省略する。腐食の進行を毎

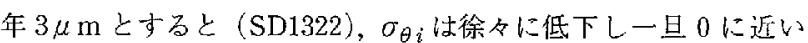
値となるが，その後增加する。内压が上昇し続けているにもかか わらず， $\sigma_{\theta i}$ が上昇するのは興味深い。さらにこの現象が顕著 となる, 腐食の進行速度が每年 $5 \mu \mathrm{m}$ の場合について下記で検討 する。

腐食の進行を毎年 $5 \mu \mathrm{m}$ としたとき（SD1522）の計算結果を 図 6 に示す。この場合には，オーバパックがすべて腐食しつくす のは4万年後である。図6(a)よりわかるように，原涂々に低 下して，約 3 万年後に最小値となるが，只の後増加に転ずる。図 6(b)に $\sigma_{\theta}$ の平径方向分布を示す。これからわかるように， $\sigma_{\theta}$

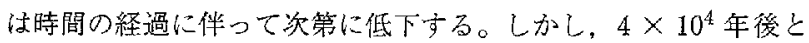
$10^{5}$ 年後を比べると，坑壁の近傍の $\sigma_{\theta}$ は $10^{5}$ 年後の方が大きい。 これは，大きな内圧に上る半径方向の応力で，坑壁付近に緩名領
域が生じ，周方向に大きく伸びるので，周方向の応力は压縮に転 ビたと考えられる。周方向への伸びは当然ポアンン比の大きさに 依存する。今回使用した構成方程式では，(8)式からわかるよう に, 破壞の進行に伴ってポアソン比が初期值より徐々に増加し, 次第に 0.5 に近ついていく。坑壁付近の応力の挙動は, ポアンン 比の仮定に大きく左右さ机ると推察された。そこでポアソン比に 関する仮定を変えて計算してみることにした。

ポアソン比を常に0とした計算結果を図 7 に示寸。この場合, $\sigma_{\theta i}$ は約 2 万 5 千年後に 0 となりその後も低下する。そのため引 張破藵が坑壁よりかなり奥まで進行する。また，腐食が終了して も破懐は時間の経過に伴い進行する。次いで, ポアソン比を常に 0.2 とした場合を計算してみな。結果は示さないが, 傾向はポア ソン比常に 0.0 とした図 7 と同じであった。さらに，ポアソン 比を常に 0.4 とした場合を計算してみた。その結果は，ポアソン 比が徐々に增加して 0.5 に近づいていくとした図 6 の計算結果に むしろ近いものであった。

なお，ポアソン比の初期值の影響について調べるため，ポアソ ン比の初期值が 0.0 と 0.4 の場合についても計算してみた。この 場合には，(8)式に従って，ポアソン比は破壞に伴って徐々に大 きくなるとの仮定をおいた。その計算結果は図6に近く，仮定し た条件下では, ポアソン比の初期値の影響は比較的小さいことが わからた。

以上の結果，ポアソン比に関する仮定が大きな影響を及ぼすこ とがわかったが, 構成方程式のパラメータのの及ぼす影響につ いて調べてみることにした。既報で述べたように, 強度破壊点以 降における応力一整曲線の傾きは $m / n_{0}$ に依存し，この值が大き いほど延性的となる。図8に，標準条件下で (SD1222)， $m / n_{0}$ が両極端の場合の結果を示す。まず，図 $8(\mathrm{a})$ には $n_{0}=20, m=$

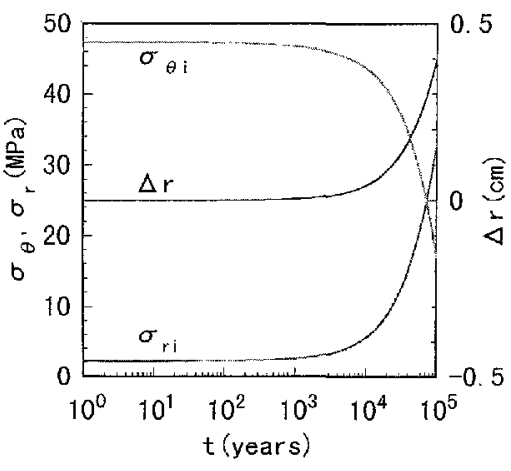

図 5 腐食の進行が毎年 $1 \mu \mathrm{m}$ と緩やかに腐食 が准行する場合の計算結果 (SD1122)

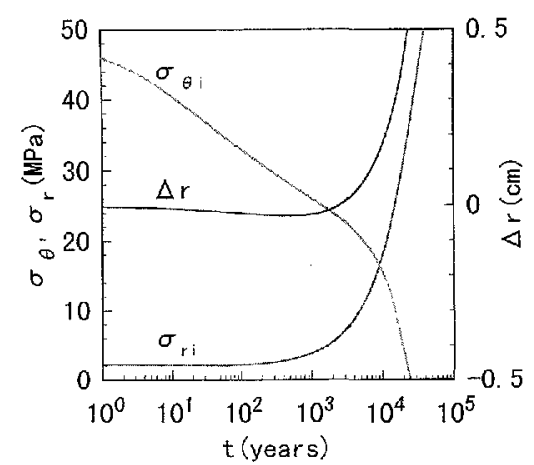

図 7

ポアソン比常に0とした場合の結果 (SD1522)

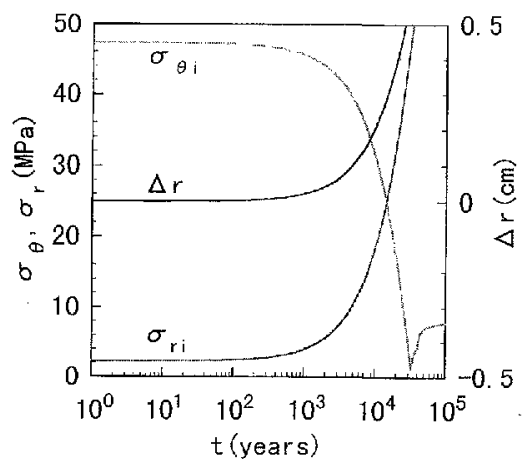

(a) $\sigma_{\theta i}, \sigma_{r i}$ 斿上び $\Delta r$

図 6 腐食の進行を毎年 $5 \mu \mathrm{m}$ としたときの計算結果（SD1522）

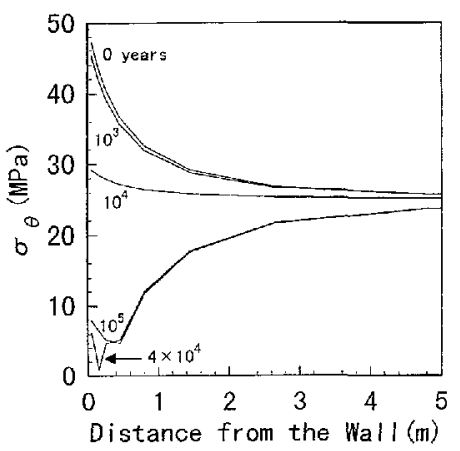

(b) $\sigma_{\theta}$ の半径方向の分有

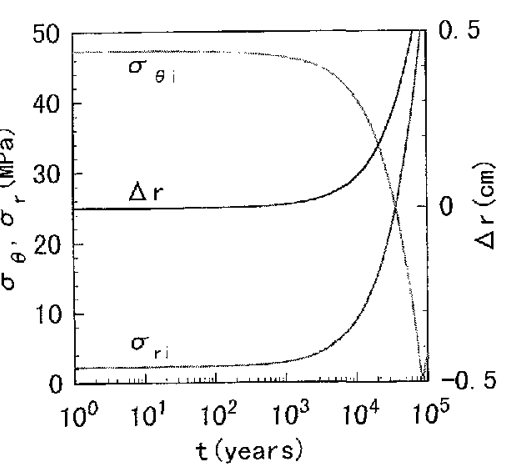

(a) 延性的な場合 $\left(n_{0}=20, m=1\right)$

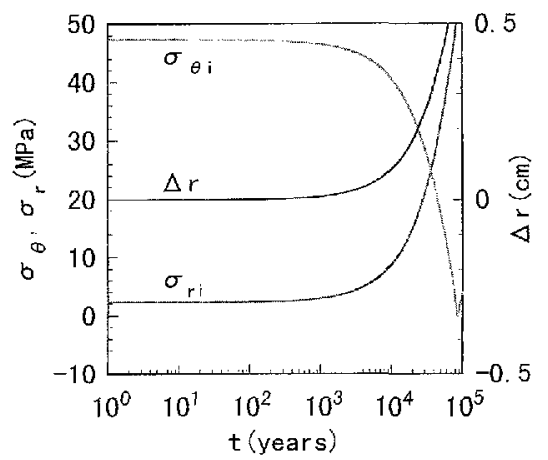

(b) 脆性的な場合 $\left(n_{0}=20, m=20\right)$ 図 8 岩盤が延性的な場合と脆性的な場合（SD1222） 


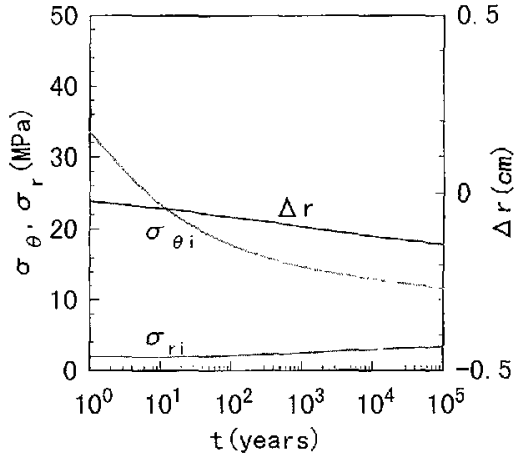

(a) $\sigma_{\theta i}, \sigma_{r i}$ および $\Delta r$

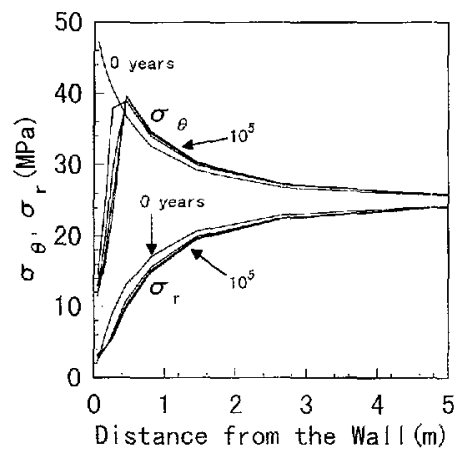

(b) $\sigma_{\theta}<\sigma_{r}$ o半径方向の分有

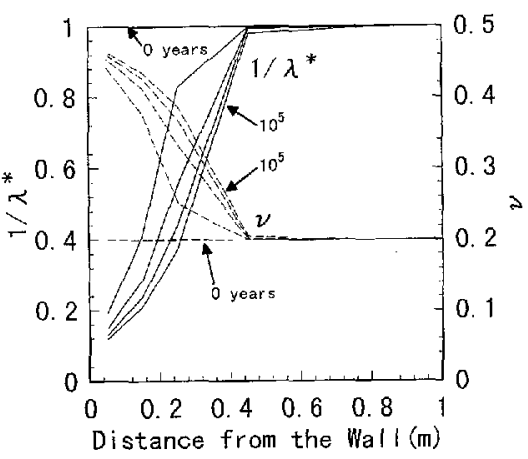

(c) $1 / \lambda *$ と半径方向の分布

図 9 充填材はあるが腐食の進行は全くない場合の結果（SD1021）

1とした場合の結果少す。このようにパラメータ老設定すると、 一軸圧縮応力下では降伏したのちの応力の低下は緩慢である。図 8(b)は $n_{0}=20, m=20$ とした場合の結果である。この場合には， 一軸圧縮応力下では，強度破壤点を超えた直後に応力が急激に低 下する。両者を比較して，計算結果は意外と似通っており，この 計算条件下では強度破塆点以降の応力一歪曲線の傾きは方まり影 響しないことがわかる。これは，内压により三軸压縮状態となり， 応力一歪関係が延性的になるためであると考えられる。

$3 \cdot 2$ 時間依存性の大きい場合 $\left(n_{0}=10\right)$

$3 \cdot 1$ と同様に，まず図 3 と同様に，腐食の進行のない場合の 計算例を図 9 に示す $(\mathrm{SD} 1021)$ 。図 9(a)より $\sigma_{\theta i}$ の低下がかな り大きいし，またわずかたが $\sigma_{r i}$ が增加することがわかる。 $n_{0}$ が 小さい場合, 強度と此べて小さい応力が加わり続けても, 長期間 では大きな変形が生ずる。図 $9(\mathrm{~b}) に \sigma_{\theta} と \sigma_{r}$, 図 $9(\mathrm{c}) に 1 / \lambda^{*}$ とレの半径方向の分布示す。いずれも，図 $3(\mathrm{~b})$ と同じく，初 期, $10^{3}$ 年後, $10^{4}$ 年後, $4 \times 10^{4}$ 年後, $10^{5}$ 年後の 5 本の曲線を 重抟きしたものである。而図より，104年後までの変化が大き くその後はあまり変化しないこと、緩み領域は坑壁加ら約 $0.5 \mathrm{~m}$ の籁囲であることがわかる。緩文領域では坑壁近くで $1 / \lambda^{*}$ が減 少し，それに呼応してレが增大している。この場合も，ポアンン 比の初期值を含め，常に 急速に小さくなり緩み領域が大きく広がる。

次に，腐食の進行が毎年 $1 \mu \mathrm{m}$ と紘やかに腐食が進行する場合 の計算例图 10 に示す (SD1121)。内压が小さい間，坑壁近傍 が緩むので $\sigma_{\theta i}$ は一旦低下する。やがて内圧の上昇に伴って $\sigma_{\theta i}$ が上昇するのが特徵的といえよう。 $\sigma_{r i}$ は内圧とほは等しく，時 間経過に伴って順次上昇する。腐食の進行が每年 $2 \mu \mathrm{m}$ の場合 は（SD1221），内压の上昇速度が速いものの傾向としては

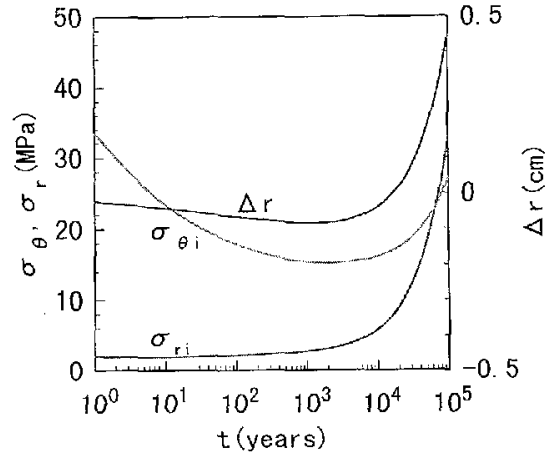

図 10 恀食の進行が每年 $1 \mu \mathrm{m}$ と緩やかに腐食が進行する場合の計算 結果 (SD1121)

SD1121 と変方らない。

なお，腐食の進行が毎年 $3 \mu \mathrm{m}$ の場合を検豇した（SD1321）。 3・1のSD1322の場合, トンネル壁の応力が一旦引張となった が、今回はずっと珐縮のままであった。

さらに，腐食の進行を早くし毎年 $5 \mu \mathrm{m}$ とした場合（SD1521） 图 11 に示守。3・1の図6(SD1522) の場合， $\sigma_{\theta i}$ が一旦 0 近くまでとなったが，今回は約 $10^{3}$ 年後に早くも上昇に䎐じた。 この現象は次のように説明できるのではないかと考えられる。

(1) 図 11(a)，(b)上りわかるように，内压が大きくなる前に 坑壁付近が緩む。図 11(c)よりわかるように，結果としてこの部 分のポアソン比は大きくなる。

(2) 内圧が次第に大きくなると， $\sigma_{\theta i}$ は少しずつ下がるが，そ の下がり万は小さい。この場合，坑壁近傍の岩盤のポアンン比が 大きくなるので $\theta$ 方向の伸びが大きく，よって $\sigma_{\theta i}$ は引張となら

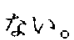

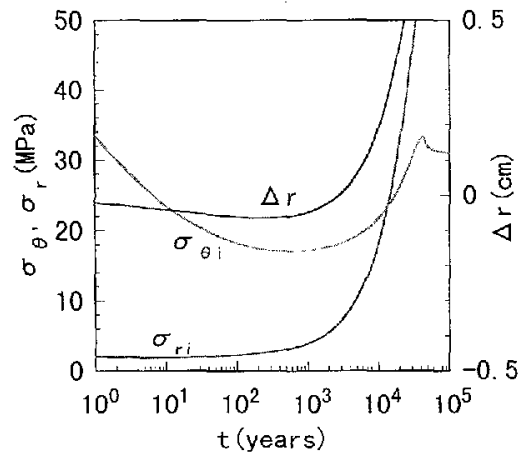

(a) $\sigma_{o i}, \sigma_{r i}$ 掠よび $\Delta r$

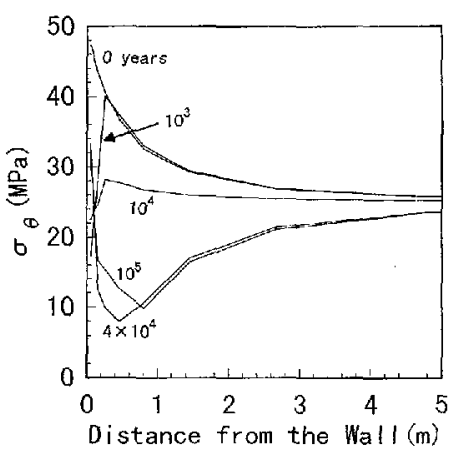

(b) $\sigma_{\theta}$ の半径方向の分布

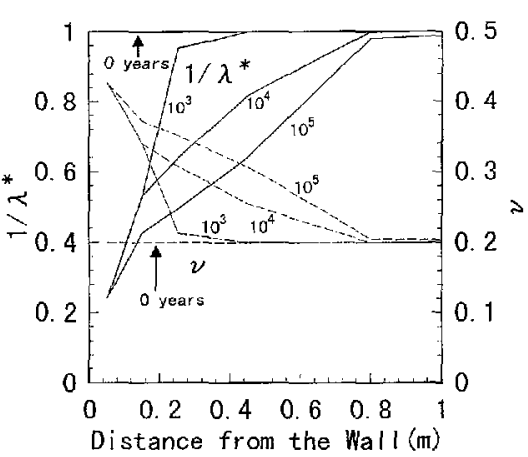

(c) $1 / \lambda^{*}$ と牛径方向の分布

図 11 腐食の進行を每年 $5 \mu \mathrm{m}$ としたときの計算結果（SD1521） 


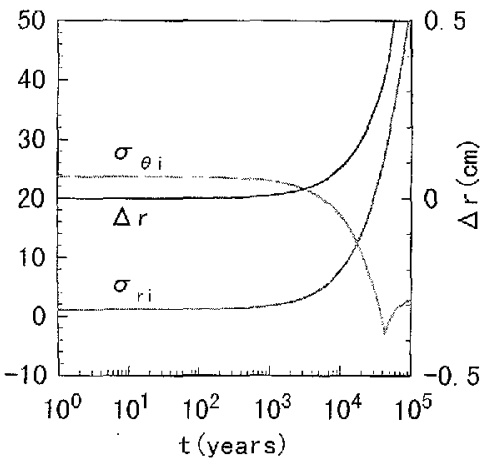

图 12 媣さが $500 \mathrm{~m}$ のときの計算結果 (SS1222) $\left(n_{0}=20, m=10\right)$

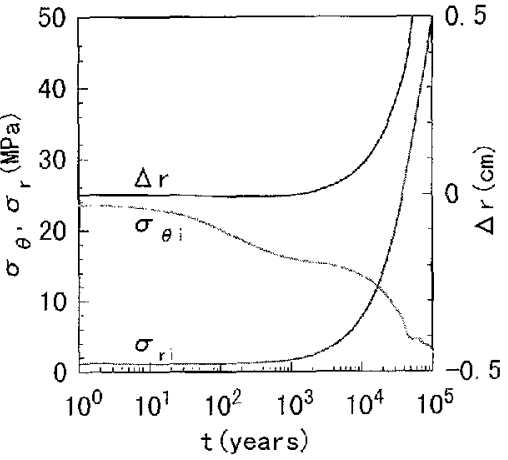

染さが500 m のときの計算結果（SS1221） $\left(n_{0}=20 . m=5\right)$

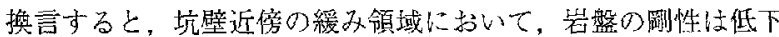
して㧍り，ポアソン比は大きい。坑壁に内压が加わると，坑壁と 健全交岩盤に扶まれた緩灭領域蛙，半径方向に王縮されるととも に周方向に膨らむので，坑壁近傍の周方向応力は圧縮䚋に增大す ることがある。

3・1 と同㥞にポアソン比の仮定の影響を調べたところ, 定性 的な結果は $3 \cdot 1$ と同じであった。また，䊤成方程式のパラメー 夕のの影響についても調べたが，定性的な傾向は $3 \cdot 1$ と同に であり，この場合にも強度破壊点以降の応力一歪曲線の傾きの影

響は少ないことがわかった。

\section{3 ・3 地圧の小さいとき（深さ $500 \mathrm{~m}$ の場合）}

まず，時間依存性の小さい岩盤の場合 $\left(n_{0}=20\right)$ について検 討した。内圧の加加らない場合（SS1022）粘性的变形は汪とん ど認为られなかった。ついで腐食の進行速度が每年 $1 \mu \mathrm{m} の$ とき （SS1122）を計算した。予想通り地圧が小さく，内压の增加に従 い, $\sigma_{r i}$ は堌加し $\sigma_{\theta i}$ は低下する。さらに腐食の進行速度を毎年 2 $\mu \mathrm{m}$ （SS1222）として計算したのが图12である。約 4 万 5 千年 まではほほ弹性的に振る舞い，それ以降，半径方向の㐫力によっ て緩队領域が進展した。周方向の応力は 4 万 5 千年の時点でわず 加织引張応力が作用するが，緩及領域の発生に上って圧縮側へと 变化している。さらに腐食の進行速度の大きい場合 (SS1322) も計算してみたが，上記と同様の傾向が見られた。

次に，時間依存性の大きい岩盤の場合 $\left(n_{0}=10\right)$ について检

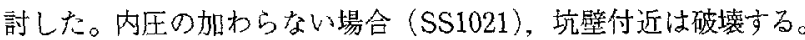
腐食の進行速度を毎年 $1 \mu \mathrm{m}$ 上り順次大きくして計算した。順向 はさして変わらなかったので，毎年 $2 \mu \mathrm{m}$ の場合（SS1221）の み図 13 に示す。地圧が小さいので，弾性論から計算した $\sigma_{\theta i}$ は 早期に引張となるはずであるが，計算結果では引張とならない。 しかし，1万年を過ぎても $\sigma_{\theta i}$ が少しずつ低下し続ける。岩盤の かなり奥まで楥み領域は拡大し，このような場合には内压により $\sigma_{\theta i}$ が压縮側に增大寸る効果が小さくなる可能性を示唆している。 この点については，考察で触れることにする。

3・4 トンネル径, ベントナイト体積弹性率，腐食による体

\section{積膨張率の及ぼす影结}

ここまでは，坑道径が $1.0 \mathrm{~m}$ の場合について調べてきた。 1.0 $\mathrm{m}$ 程度の坑道だとあらゆる作業を自動化する必要がありそうで ある。他方，1.5 m であれば，機器の故障時などの緊急時には一 時的に人が入って作業することは可能であるう。計算は，時間传 存性の小さい岩盤の場合（LD1122，LD1222など），時間依存性 の小さい岩盤の場合（LD1121，LD1221など）について行った。 玾道径が大きいと内圧の上昇は小さくなる。これはあらかじめ予 测されたことである。

また，充填材の弾性率を大きくした場合（SD2122，LD2122

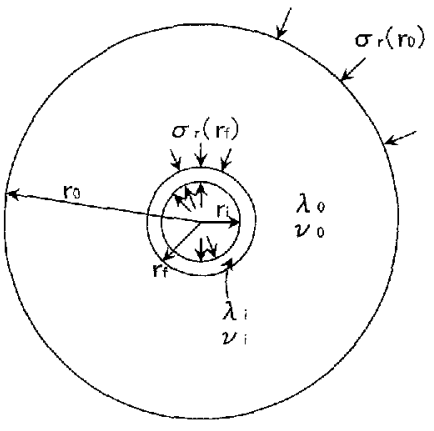

図 14 弾性解用いて計算機シミコレーション 結果を检討するためのモデル。坑道壁得 加ら $r_{f}$ までのコングライアンスは ポアソン比性。安の外側のコンブ

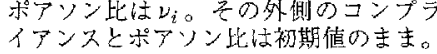
$r_{0}$ は $r_{i} \sigma 300$ 倍

など），腐食による体積膨張率を変えた計算も行った。たとえば， ベントナイトの弾性率を大きくする内圧の上昇が大きくなる。 LD1222 とLD2122 (速度半分, 体積弾性率倍) はほとんど同じ 結果になった。

坑道径，充填材の体積弾性率，腐食による体積弾性率を変えて 検討した結果も，あらか心め予想した通りと疛った。

\section{4、考}

シミエレーションで現れた次の事項は重要と考えられる。すな わ方，最初緩为領域が坑壁上り順次奥人と広がるが，その後内压 が増加すると䋸んだ領域は半径力向に圧縮されて周方向に伸びよ うとする。その結果，内圧の上昇に伴って $\sigma_{\theta}\left(r_{i}\right)$ が上昇する場 合のあることが，シミュレーション結果で示された。これは，坑 壁近傍のコンプライアンスが低下した状態で内圧が加わると，坑 壁での $\sigma_{\theta}\left(r_{i}\right)$ が压縮になることを意味している。このようなこ とがありえるかどうかを，图14のように簡略化したモデルによ。 て検討する。

図 14 では，坑道径 $r_{i}$ より $r_{f}$ までがコンプライアンスが粠なる 領域であり，この部分のコンプライアンスを $\lambda_{i}$ ，ポアソン比を $\nu_{i}$ と記すことにする。 $r_{f}$ より外径 $r_{0}=300 r_{i}$ までのコンプライ アンス $\lambda_{0}$ とポアソン比 $\nu_{0}=0.2$ は，初期値のままとする。この とき， $r_{f}$ に㧍ける半径方向の応力 $\sigma_{\mathrm{r}}\left(r_{f}\right)$ は，次式で与えられる (日本機械学会, 1977 ; 鵜户口ら，1968）。

$$
\sigma_{r}\left(r_{f}\right)=\frac{2 \sigma_{r}\left(r_{i}\right) \lambda_{i} \frac{r_{i}^{2}}{r_{f}^{2}-r_{i}^{2}}+2 \sigma_{r}\left(r_{0}\right) \lambda_{0} \frac{r_{0}^{2}}{r_{0}^{2}-r_{f}^{2}}}{\lambda_{i}\left(1-\nu_{i}\right) \lambda_{0}\left(1+\nu_{0}\right)+2 \lambda_{i} \frac{r_{i}^{2}}{r_{f}^{2}-r_{i}^{2}}+2 \lambda_{0} \frac{r_{0}^{2}}{r_{0}^{2}-r_{f}^{2}}}
$$

(9)式から計算した $\sigma_{r}\left(r_{f}\right)$ を次式に代入すれば，坑壁での $\sigma_{g}\left(r_{i}\right)$ が求まる。

$$
\sigma_{\theta}\left(r_{i}\right)=-\frac{\frac{r_{f}^{2}}{r_{i}^{2}}+1}{\frac{r_{f}^{2}}{r_{i}^{2}}-1} \sigma_{r}\left(r_{i}\right)+\frac{2 \frac{r_{f}^{2}}{r_{i}^{2}}}{\frac{r_{f}^{2}}{r_{i}^{2}}-1} \sigma_{r}\left(r_{f}\right)
$$

比較的わかりやすいと思われる $\sigma_{r}\left(r_{i}\right) / \sigma_{r}\left(r_{0}\right)=20$ 場合につい て検討してみる。この場合，全域のコンプライアンスとポアソン 比が一定ならば $\sigma_{\theta}\left(r_{i}\right)=0$ のはずである。

ポアソン比は(8)式に従って奖化するとして，(9)式と(10)式よ り計算した結果が図 15 である。横軸は $\lambda_{\mathrm{f}} / \lambda_{0}$ であり， $r_{f} / r_{i}$ を 1.1ー2.0まで変えて計算したときの $\sigma_{\theta}\left(r_{i}\right) / \sigma_{\theta}\left(r_{0}\right)$ を示した。 $r_{f} / r_{i}$ が比較的小さい場合, 計算結果は右下がりの曲楾となる。 


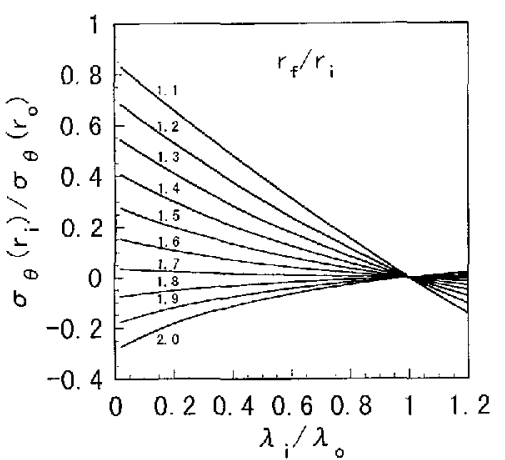

图 15 弾性解（図14に示したモデル）。ポアソン比 $\nu_{i}$ は(8)式に従って 大きくなっているとした場合

$r_{f} / r_{i}$ が 1.7 ではほとんど横軸に平行となり， $r_{f} / r_{i}$ がそれ以上に なると計算結果は右上がりの曲線となる。この計算絬果より， $r_{f} / r_{i}$ がある範用内にとどまっていれば，外压 $\sigma_{r}\left(r_{0}\right)$ の 2 倍とい う大きな内医 $\sigma_{r}\left(r_{0}\right)$ 妾受けていても, 坑壁の周方们応力 $\sigma_{\theta}\left(r_{i}\right)$ 岵压維となる場合があるといる。この結果は，多くの場合，内

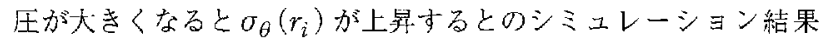
と傾向が一致しているといえよう。また，図13のように坑壁か らかなり奥まで岩盤が損傷した瑒合には， $\sigma_{\theta}\left(r_{i}\right)$ の上昇はあま り期待できないことの定性的な説明にもなっている。

計算機シミュレーションによれば，ポアソン比が計算結果に及 ばす影橥が大きかった。これを定性的に検討するために，他の条 件は図 15 の場合と同じとして，ボアソン比は全域で初期值 0.2 であるとした計算結果を図 16 に示す。この場合は， $r_{f}$ が坑壁の ごく近傍にとどまっている場合を除いて $\sigma_{\theta}\left(r_{i}\right)$ は引張となるこ とがわかる。計算譏シミュレーションでも，ポアソン比を同様に 0.2 のまますると引張破圗が奥まで進行した。図 16 に示した結 景は、この計算機シミュレーション結果をある程度説明している と見な劣れる。

(9)式と $(10)$ 式は多くの定数考含文, $\sigma_{r}\left(r_{i}\right) / \sigma_{r}\left(r_{0}\right)=2$ と仮定 した場合でも， $r_{0} / r_{i}$ やポアソン比の初期値の及ぼす影響につい て検討する必要がある。この内， $r_{0} / r_{i}$ は，その值を大きくして も計算結果がほとんど変わらないように300とした。ポアソン比 の初期值を変えた場合も検討したが，初期值が大きいほど坑壁の 周方向応力 $\sigma_{\theta}\left(r_{i}\right)$ が圧縮となりやすいという予想通りの結果を 得た。

なお，古くより内压孛受けた円简の塑性が，検討されてきた。 この場合は内圧加增加するのに徉って $\sigma_{\theta}\left(r_{i}\right)$ は徐々に減少し最 低值（引張応力）を取った後，上昇に転じる（Hill, 1971）。本研 究のシミュレーションと関倸のある事項であるが, 閉じた解析解 はないので指摘するだけにとどめる。

\section{5.まと め}

計算結果によれば，ポアソン比の影響がもっとも大きい。すな わち, 破壊の進行に伴ってポアソン比が增大する限り, 内王が增 加しても坑道壁面の周方向応力は压縮側にとどまるので, 坑道周 讱岩盤の損傷は比較的軽微で交る。多くの岩種にとってこの考至 が成り立つ可能性がある。岩石の横歪は, 強度破壊点以前のかな り早い段階より大きくなる。これをダイラタンシーと呼んでいる。 ほとんどの岩石の場合, 破壊の進行に伴って, シミュレーション で仮定したようにポアソン比が大きくなっていくであうう (Lama and Vutukuri，1978)。ただし，不明な点がまだまだあ るのでポアソン比に関する研究を続ける必要がある。特に主応力

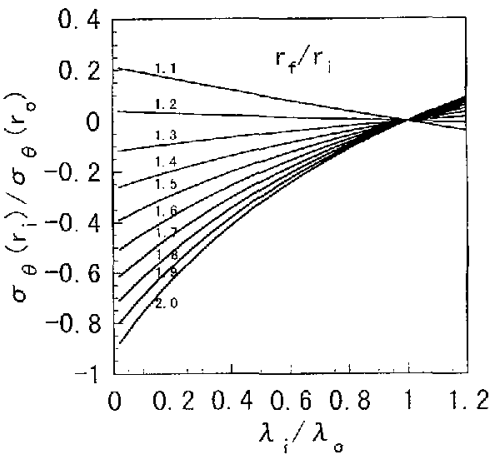

図 16 弾性解 (威 14に示したモデル)。ポアソン比 $\nu_{i}=0.2$

の一つが弓張となった場合にどうなるが恃不明な点が多いので検 徍方る必要がある。また，岩石と一口にいっても，多くの種類が あり，例外的にポアンン比が異常な变化をする場合もありえるの で, 内圧の加わる坑道の候補地選定に当たっては慎重にポアソン

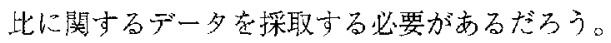

構成方程式のパラメータ $n_{0}$ と $m$ については次の事項が判明し た。まず， $n_{0}$ の影響がかなり大きいことがわかった。短期的な データは得られているが, 長期にわたる現象についての数值は不 明である。長期の場合には， $n_{0}$ は変化する可能性がある(Anderson and Grew，1977）。予想に反して $m$ の影響は比較的小さ い。坑道内に何もないと， $m$ が大きく脆性的な岩盤では急速に 破壊が奥へ上准行するが，今回検討したケースでは充填材が内部 にある。このような場合, 坑道壁面近傍のコンプライアンスが増 加して内空変位が生ずると, 内压が上昇して急激な破壊の進行が 緩和される。このような事象のため， $m$ の影響は比較的小さい と思われる。すなわち，内圧の増加は圧縮による緩み領域の拡大 を押さえる効果があるので，岩盤が脆性でも破㠃は急速に生じな い。この点が通常の充填物のない場合ともっとも異なる点である。

今後の課題として, 繰り返しになるが特に重要な点を 2 つ举げ て扔く。(1)ポアソン比の正確なデータの収得。(2)引張応力下での 研究が決定的に不足しているので,このデータの收得。この2 点 沬早急に対策を施す必要があると洘える。

\section{引用文献}

Anderson, O. L. and Grew, P. C. (1977) : Reviews of Geophysics and Space Physics, 15, p. $77-104$

Hill, R. : The Mathematical Theory of Plasticity, p. 106-114, Oxford Univ. Press (London)

稻田善紀 (1997)：岩盤工学，第8 章, 森北出版（東京）

Janach, W. (1977) : Int. J. Rock Mech. Min. Sci. \& Geomech. Abstr., 104, p. $209-215$

Lama, R. D. and Vutukuri, V. S. (1978) : Handbook on Mechanical Properties of Rocks, Yol. 3, No. 1, p. 117-182, Trans Tech Publications (Aedermarinsdorf)

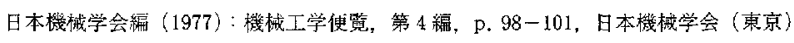
大久保䣬介 (1992)：资源と素材，Vol. 108，p，601-606

大久保諴介・金豊年 (1993)：资源と素材，Vol. 109，p. 209-214

PNC (1991)：地層処分研究開発の現状（PNC TN 141091-009），P. 30-38，動力炉。 核然料開発事業闷 (東京)

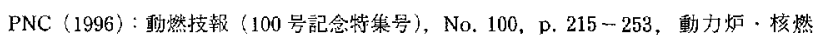
料開発事業团 (東京)

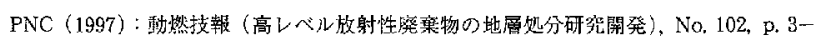
20 , 動力灯 ·核然料関発事業団（束京）

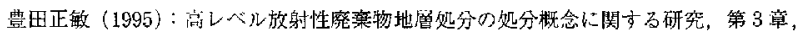
東京大学博士論文

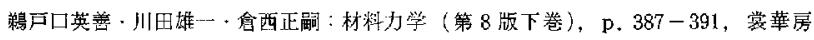
(柬京) 